УДК 182-162:1

Ковпік C.I.

доктор філологічних наук, професор Криворізький педагогічний інститут ДВНЗ «Криворізький начіональний університет»

\title{
ПОЕТИКА ГУСТАТИВНОГО У ЦИКЛІ КУЛІНАРНИХ КАЗОК ДЛЯ ДІТЕЙ
}

У статті з точки зору поетики густативів проаналізовано ичикл кулінарних казок для дітей. Авторка статті помітила, щзо 3. Мензатюк дуже вдало ввела маленького читача у світ украӥнської кулінарї та кухні, який не лише збагачує й формує вже наявні в уяві дітей густативні образи страв (від борщу до узвару з усім багатством борошняної дрібноти), а й робить їх значними та повноцінними, збагачуе дитину знаннями про харчування украӥнців, перетворюючи майже все цее в казку, письменниия упевнено вводить дитину в світ далеко не казкового кухонного «смачного буття украӥнців».

Ключові слова: густативи, література про кулінарію. 
В статье с точки зрения поэтики густативов проанализировано циикл кулинарных сказок. Автор статьи заметила, что 3. Мензатюк очень удачно ввела маленького читателя в мир украинской кулинарии и кухни, который не только обогащает и формирует уже существующие в представлениях детей густативные образы блюд (от борщза до узвара со всем багатством мучных мелочей), но и делает их полноценными, обогащет ребенка знаниями о питании украинщев, превращая все это в сказку. Писательница уварено вводит ребенка в мир далеко не сказачного «вкусного бытия украинцов».

Ключевые слова: густатив, литература о кулинарии.

The article focuses on the essence of the "gustative" notion and its interpretation in literature tale culinary for children. So, it is noted that Literarygustative trend in the modern history and criticism of the literature determined the basic content of the concept "gustative" and also formed a concept of the gustative images in literature. The gustative image considered as complete system of contentformal qualities and function which constitute a series of olfatic factors of both the individual products and cooked dishes as well as the processes of its consumption by many contemporary literary critics. This understanding of gustative image contributes not only to study it as an element of the text, but to include it with linguistic means, tropes and stylistic figures in general philological analysis of literary work, its interpretation, which is based on the famed approaches, methods, technologies, schemes of analysis.

Keywords: gustative, literature tale culinary.

Поява i тематика циклу казок 3. Мензатюк зі «смачною» назвою «Зварю тобі борщику» може свідчити про початок формування нового як за змістоформами, так і за ознаками та найсуттєвішими функціями жанру літературної казки для малечі, адже це власне справжня «кулінарна» або «апетитна» казка. «Замісився» цикл саме таких творів, зазначила сама авторка, в одному 3 інтерв'ю тоді, коли вона старанно готувала найвідоміші та найпоширеніші в Україні страви для своїх близьких - борщ і вареники. 
Ввійшовши в досить широке коло по-різному цікавих пізнавальноосвітніх казок для дітей, цей цикл не міг лишитися не поміченим уже тому, що творів саме такого плану практично ще не було. До того ж, 3. Мензатюк вирішила цими творами не просто розвивати пізнавальні потреби дітей, а й привчати їх до здорового способу харчування, шляхом залучення їх до участі в самих процесах приготування дуже різних і не менш «смачних» страв, тобто до такої цікавої «діяльності» не лише для себе, а й для своїх рідних та близьких.

3. Мензатюк грунтовно осмислила: для досягнення поставлених цілей, мабуть, буде замало звичайних технологічних описів рецептів потрібна зовсім інша «нетрадиційна» форма подачі художньої інформації. Так почали «писатися» справжні казкові історії про більш ніж звичні дії дорослих для дітей: по-перше, виявилося, що окремі продукти (інгредієнти) для майбутніх страв можуть не просто купуватися й приноситися дорослими 3 городів чи 3 магазинів, а й самі (не завжди відомо звідки та як) «появлятися» на кухні; по-друге, рухи й дії дорослих при приготуванні страв можуть видаватися настільки цікавими i навіть дещо дивними та незвичними, що у дітей виникає бажання їх повторювати; по-третє, участь дітей у процесі приготування їжі неминуче робить його ще більш незвичним - то яким же має стати процес пї споживання («майже»!) самостійно приготовленого.

Напевне і справді варто в статті виявити й охарактеризувати не лише реальну, а й удавану та ще й «казкову» «незвичність» «доросло-дитячого співробітництва» на кухні: від небуденного добору й обробки окремих, часом відомих, але незвичних «персоніфіковано-оживлених» продуктів i таких же «прийомів» виготовлення відомих дорослим і дітям - як саме авторка-казкарка намагається впливати не тільки на основні сенсорні реакції, а й на переживання, уяву та роздуми читачів або слухачів.

Тут 3. Мензатюк зробила іï перший і дуже вдалий вибір: необхідно говорити дітям не стільки про майстерність, скільки про цікавість і «дивовижність» звично-буденної страви, про їхню можливу незвичність. 
I все це потрібним стало не тільки для того, щоб збудити споживацькі потребі малих читачів, а перш за все для того, щоб викликати у них спалахи емоцій та уявлень, а то і цілі «букети» емоційно багатих реакцій, настроїв, станів і навіть захоплень тощо.

Помітно цінними видаються прагнення авторки викликати у дітейреципієнтів не лише співчуття та співпереживання, а й співучасть у процесі елементарної кухонної «діяльності».

Прояви саме таких прагнень дітей-читачів (або слухачів) починаються уже зі сприйняття і усвідомлення назви збірки - під їі впливом реципієнт одразу потрапляє в ситуацію, в котрій він сам нібито констатує його цілеспрямований намір виконати конкретну дію - «Зварю тобі борщику». Але вже незабаром з'ясовується, що це буде не звичайне побутове «куховарство», а своєрідне, напівказкове, «дійство» людини, яка хоче й може весело й цікаво творити смачні та ще й «корисні» страви: небуденний борщ, веселу кашу, «засмаглу» картопельку, «булькату» яєчню, «крилаті» голубці, млинці та «круглолиці» калачі.

Як бачимо, уже цей запропонований 3. Мензатюк перелік страв, - це не просте, а цікаве, пересипане епітетами «меню», в якому «живуть» складні і незвичні звичаєві страви українців.

Оскільки у такому «меню» як і в самому житті, все починається 3 борщу, саме з нього й почала авторка творити цикл.

Уже 3 першої страви вона підібрала не лише смачні ароматичні та поживні, а й «веселі» та «цікаві» лікувально-оздоровчі інгредієнти.

Так, маленький читач дізнається про те, що буряк добре «діє на рани» і послаблює болі в животі, а морква лікує очі. А ще дитина може дізнається про те, що всі людські «болячки» дуже «бояться» цибулі. I уся ця інформація у процесі саме такого способу приготування борщу в уяві і в свідомості малечі формує не тільки суто густативний образ майбутньої страви, а й знання про неї як про приємно-лікувальний «засіб». Так дитина вперше дізнається про те, що справді найкращі ліки - це харчі. 
Окрім того, розповідь казкарки про підготовку до виготовлення борщу покликана ще й максимально збудити апетит майбутнього «кулінара», адже бажання до їжі далеко не завжди «дружить» із дітками. 3 цією метою авторка використовує то незвичні густативно-грайливі лексеми («сметанка-білянка»), то уявно-густативні гіперболи («смачний боршик... пахне аж у хмарі») [Мензатюк 2012 : 9], то інші засоби, які не лише приваблюють смачними ароматами, а й зовнішнім виглядом. А ще смачним цей борщик виявився ще й тому, що його хворому Івасику готували мама і сестричка.

Наприкінці казки 3. Мензатюк слушно відзначила, що «здоровий борщик» справді помітно вилікував хлопчика: «...з '̈в Івась ложку борщуу ліва щзіка порожевіла, з їв другу - права зарум'яніла, виїв усю миску тай засміявся〉 [Мензатюк 2012 : 10].

У наступній «апетитній» казці «Каша» увагу малечі привертає те, що пшоняна каша додає і здоров'я, і сил усім тим, хто іiі їсть. Про це старша сестричка Івася Олеся розповіла навіть змієві-нападникові: пшоняна каша не проста, а золота, бо вона досить довго і в певній та чіткій послідовності всіх дій готується і «на вогні», i «на жару», довго «вмліває, щуе й масла в ній ціла грудка, бо маслом каші не зіпсуєш!» [Мензатюк 2012 : 13]. I це неабияк підсилює ефект «чарівності» звичайної страви і по-своєму переконує маленького читача в тому, що кашу потрібно їсти 3 багатьох причин: вона і корисна, і поживна, одним словом, «золота». А разом ця незвична творча презентація не звичаєвої, а просто звичної страви породжує в дитині бажання з’їсти іiі вже хоча б для того, щоб не боятися навіть змія, а може не одного?!.

Дещо буденіше, «побутовіше» сприймається назва наступної казки «Картопля». Але як тільки авторка починає персоніфікувати картопельку, яка сама себе презентувала так, що сконцентрувала на собі неабияку увагу: то цей овоч дістається в Україну із самої Америки, то він вільно й легко сходиться й вільно розмовляє 3 усіма головними та другорядними персонажами. Картопелька звертається до діток-слухачів Івася та Олесі. Вона запросила їх «мандрувати» разом 3 нею. А коли до цієї подорожі 
долучилися ще й батьки дітей (аби діти не заблукали), вони всі беруть 3 собою такі потрібні речі як сірнички, щоб гід Картопля, коли діти зголодніють, змогла пригостити своєю печеною «смакотою».

Не давши сірників у руки дітям, авторка процес запікання картоплі констатувала досить узагальнено: тато «напік картоплі в червоному жарі, мама ї̈ почистила, сіллю присолила - ох, смакота!» [Мензатюк 2012 : 20]. I хоча картопля виявилася позбавленою авторкою лікувальних здібностей i функцій, цей овоч, і твір не втратили їхньої привабливості.

Дуже цікавою виявилася казка «Вареники». У ній розкрита така (прямо-таки «потужна») сила смаку страви, що саме нею діти, Івась та Олеся, на смерть «загодували» навіть ненажерливу відьму.

Не даючи детального опису «технологій» приготування, казкарка перераховує довгий ряд начинок для вареників, але найсмачнішими i для самих дітей, i для дорослих, i, звичайно, для відьми виявилися: вареники 3 маком та вареники 3 вишнями, «невеличкі вареники, солоною бринзою начиненні》 [Мензатюк 2012 : 26]. Відьмі так сподобалися вареники, що вона не просто їла їх з апетитом, а «молотила їх, ще й макітру облизувала» [Мензатюк 2012 : 27]. На цей раз сила особливих смакових якостей начебто й звичної для українців страви виявилась такою, що вона здатна долати навіть «чорну силу». Це завдяки цій страві діти рятують своє життя, а ще призвичаюють відьму до дивовижних вареників, які вона навчилася сама ліпити.

Так, справді казково і більш ніж переконливо презентує авторка одну 3 найулюбленіших страв нашого народу - вареники. Не менш дивною подається авторкою й така проста і звична страва - як яєчня. На цей раз, додаючи до назви страви багато власне художніх означень, зокрема й образних епітетів, казкарка кожного разу перетворює цю страву на щось незвичайне - навіть у «гетьманську» яєчню. I все це підтверджується неабияким переліком тих продуктів, із якими смажать усі ці «варіанти» страви українці: 3 ковбасою, з печерицями, з телячим язиком та салом, чим максимально напружується майже вся «гама» смакових рецепторів дітей. 
Та цим авторка-казкарка не обмежилася - вона запропонувала малечі «додати» до відомого рецепта «гетьманської яєчні» ще низка смаколиков: трохи свіжої сметанки, зелені, масла та ін. Але чи не найпомітніше «дивною» робить цю страву те, що процес смакування нею, на думку, авторки, має здійснюватися під особливо оптимістично обнадійливий словесний супровід:

\section{Яєчня не проста, \\ Яечня золота, \\ Їж її, Іване, \\ То виб'єшся в гетьмани ! [Мензатюк 2012 : 31].}

Так дитяча цікавість до складових і до процесу приготування, до безпосередньої участі в ньому самих дітей та ще й «навіюваний» супровід неабияк посприяли не просто приємному, а захопленому поїданню страви - усе це справді досить помітно й багатогранно розвиває дітей, а головне - активно й цікаво долучає їх до українського, в тому числі, й до козацького кухарського духу.

Ще складнішою українською стравою видаються «Голубці», хоча вони також $є$ нібито досить звичайною, але не такою вже й буденною стравою. У 3. Мензатюк вони перетворюються на «чарівну» страву, а саме: на «рідних братиків голубів» [Мензатюк 2012 : 34]. Перевтілені в голубів голубці легко «випурхнули» 3 миски Івася, саме тоді, коли він почав вередувати і не захотів їсти.

Цю метафору авторка вдало використала як ефективний засіб творення не лише «цікавої», а й повчальної ситуації, а головне - для породження в свідомості дитини художньо-образного уявлення й досить глибокого роздуму чи домислу.

А далі письменниця створює ще одну досить не просту ситуацію: після того, як голубці «полетіли геть», ніхто не почав готувати цю страву ще раз - ніхто з родини не став знову й знову догоджати вередливому хлопчику. I тільки тоді голодний Івась дуже пошкодував про те, що він так себе повів. А казкарка ще й підсилила переживання Івася простою, i начебто «нейтральною» констатацією: «...голуби̧і були хороші. Смачні. 
Запашні, та добре вмлілі» [Мензатюк 2012 : 34], - від чого особливо помітно подіяли на хлопця (а, разом із ним, і на реципієнтів) не лише суто густативні, а й характеристично-виховні властивості й ознаки страви. Голубці набули в казці особливої художньо-повчальної сили. Та й метафоричний епітет «летючі», вжитий для характеристики цієї страви, став більш ніж доречним - він максимально візуалізував уяву хлопчика про «політ», тепер уже зовсім дивної страви.

Та на цьому авторка не зупинилася - вона подала ще одну, не менш дивну ніж попередні, ситуацію: голубці, виявляється «повернулися додому», коли хлопчик добряче зголоднів і «ринули на стіл у миску... запахли, запарували...» [Мензатюк 2012 : 34].

Тобто, ця кулінарна казка не просто вводить дитину в світ не лише густативно-чарівного бачення й контрольованого сприймання процесів виготовлення, споживання страви - вона вчить дітей по-народному шанобливо ставитися і до самої їжі, і до тих людей, котрі їі готують, котрі просто живуть поряд.

Казка «Млинці» по-своєму (хай і помітно умовно) «виводить» дитину за межі хатньої кухні - веде в особливий «їстівний ліс», де буває багато чудес: то запанує «цукрова завірюха», то з'явиться «ставок з густою сметаною», то криниця, в якій замість води - мед «золотавий, духмяний» [Мензатюк 2012 : 38]. А ще у «їстівному лісі» $є$ й «смачна хатка», стіни якої виготовлені з млинців, двері «оладкові», а замість даху «налисник». Більше того, посеред смачної хатки розстелена «ковдра із млинців», на ній - подушки з млинців.

Сповна можливо, що ця «смачна хатинка» не $є$ для більшості дітей вершиною їхнього здивування, насолоди та мрії, але вона для будь-якої дитини - неабияке джерело зацікавлення та подивування.

Так, зголодніла дівчинка Олеся, яка опинилася перед такою смачною розкішшю не просто досхочу наїлася пшеничних, гречаних, манних, яблучних, малинових, вишневих і навіть із гречаною кашею млинців, а й залишилася в цій хатці поспати, бо йй було тут і цікаво, і тепло та привітно. 
До всього сказаного, саме в казці про смачну хатку йде мова про одну властивість деяких дітей - про можливий «їстівний максималізм», котрий з'являється при споживанні ними улюбленої страви. Такої страви повинно бути дуже багато, вона має бути всюди й завжди.

I тут авторське «казкотворення» презентує таку житейську ситуацію, в якій дитяча мрія про необмежену кількість смаколиків небачено обнадіює дитину й небачено збуджує іï апетит, але одразу після сну мрія, на жаль, лишається тільки мрією. Як це зрозуміло багатьом дітям!

Стигла полуничка (та ще й із підсолодженою сметанкою!) завжди належала в Україні до не простих «дисертиків», а до найулюбленіших дитячих страв. Уже тому назва наступної казки 3. Мензатюк «Полуниці» не просто «привертає особливу увагу» - вона в первинній асоціативній уяві кожної дитини «вимальовує» настільки «апетитні картинки», що малеча одразу тягнеться до неї всім своїм єством. Та казкарці всього того замало - вона здійснює спробу настільки очуднити реальні події, що перед малечею постає «пулиничка-кралечка» й викликає інтерес - зацікавлення не лише своїми «їстівними поривами», а ще й новим буттям полунички.

Саме так досягає казкарка вищої мети іiі творчості - людяного ставлення дитини до здебільшого буденного процесу харчування. I якщо декому з «дорослих» читачів здається, що далеко не кожна сучасна дитина може по-справжньому захопитися надто узагальненою образністю, то метафоричний епітет «вередлива» одразу робить навіть цю образність максимально доступною - вередувати вміє фактично кожне малятко.

I справді, коли полуничка починає вимагати від людей не просто класти ії на тарілку («наче якусь картоплю» [Мензатюк 2012 : 42]), а ще й поміщати іï в прозорий, кришталевий або в порцеляновий посуд, де вона буде «красуватися» на людях. Полуничка настійливо вимагала від тата Олесі, щоб той не клав iï не на «тверде» порцелянове блюдо (тендітній принцесі лежати на ньому не гоже), а на щось «м'якеньке».

Так, досить майстерно, і в той же час ненав'язливо авторка i підкреслює вишуканість небуденної страви, яку й подавати слід «піднесено», і породжує досить зрілі роздуми дитини про життя-буття. 
А «неїстівні» оздоби (лялькова ковдрочка, пелюстки фіалки) та ще одна «їстівна» («сметанка-білянка») формують у дитячій свідомості уявлення про елементи окраси життя. Особливо помітно все це підсилюється тоді, коли полуничка попросила, щоб дівчинка ще й гарненько збила сметанку, щоб та стала «ще м'якіма та пишніша» [Мензатюк 2012 : 42].

Але епізод, коли дівчинка на ії смак сама додала полуниці цукру до сметанки, вмотивовується спочатку не зовсім щиро: «щоб полуниці солодше лежалося» [Мензатюк 2012 : 44]. Та виявилось така постіль дуже сподобалась полуниці, а авторка від себе додала: «Бо, правду кажучи, нема краще, як полуниці в сметані. То королівські ласощі !» [Мензатюк 2012 : 44].

Тобто, казкарка 3. Мензатюк у цій казці професійно й майстерно не лише подає дітям цікаві, олюднені й, безумовно, корисні густативно-уявні образності, не лише прищеплює їм належні смаки та здібності, а й подає їм первинні кухарські знання - дає цікавий урок того, як приготувати «посезонну» (тобто не зовсім звичаєву, а тому по-своєму вишукану) страву.

Викликає деякі роздуми той факт, що авторка написала ім'я основного, персоніфікованого, інгредієнта страви з маленької літератури це елементарна мистецька похибка чи це зроблено для того, щоб дитина без зайвих переживань сприймала ласування саме цим «персонажем»?

Мабуть, саме тому й ілюстрації до цієї казки, максимально візуалізуючи образ «полунички-кралечки», подають іï саме ягідкою; мабуть, діткам «зручніше» їсти не красуню-принцесу 3 «великими очками», а саме ягідку з «великими краплинками».

Не тільки надто «казковим» має сприйматися початок казки «Ковбаса»: до родини (та ще й у Святвечір) прийшов колядувати вовк, а за свої колядки став вимагати віддати йому або дітей, або матір родини. Тут одразу виникає роздум: чи така ситуація не налякає дуже наївних дітей, чи 
не будуть вони з неабияким острахом ставитися до переодягнених у звірів колядників.

Так, поступово й спокійно торгуючись із вовком, родина запропонувала колядникові спочатку яблучка і горішки. I тільки тоді, коли той «загрозливо» завив, родина злякалася й згадала про ковбасу, яка так прийшлася колядникові до смаку, що він знову завив, але тепер - «від насолоди» [Мензатюк 2012 : 50]. А за те, що колядника пригостили його улюбленою, м’ясною стравою, він щиро похвали іiі : «Om краса-кобаса!» [Мензатюк 2012 : 50].

Казкарка послідовно розмістивши казки в циклі, за тим принципом як подаються страви на стіл, чомусь попереду «Ковбаси» запропонувала «Полуничку» (чи то «Ковбаса» прийшла із помітним запізненням).

У казці «Узвар» авторка подає не рецепт, а саме процес приготування цього напою: вона майже детально без «казковості» описує доступний спосіб його приготування: «Перемила сушені яблука та груші, додала до них жменю вищень, та пригорщу слив, та пів жменьки родзинок. Узвар закипів, прохолов... приправила його медом...» [Мензатюк 2012 : 51].

I лише тоді, коли дівчинка перелила напій у мальований глечик та поставила на стіл, узвар «ожив» по-справжньому, став «вітатися» зі всякою іншою «смакотою»: 3 ковбасою, і шинкою, 3 бурячками та 3 хроном, 3 холодцем і з карасями в сметані, з линами й капустою, 3 фаршированою щукою і з запорізьким капусняком, зі шпигованою печінкою та з салом, із січениками та кручениками, 3 телятиною й локшиною, i, нарешті 3 найріднішими йому - 3 пампушками.

Від такого різноманіття страв у дитини обов'язково з'явиться не лише особливий апетит, а й уявлення та надійні знання про багатство звичаєвих страв, про українську національну кухню загалом.

Та й цього авторці видалося замало - вона вирішила запропонувати дітям (але тепер уже, мабуть, не зовсім для власне малечі) ще й досить романтичну історію зародження захоплень між узваром та однією пухкенькою («найкруглішою») пампушечкою. I справді, кілька діалогів 
між цими двома стравами вийшли вже не зовсім «густативними», а скоріш «дорослими». «Рятує» ситуацію хіба що деяка іронічність чуттєвих репліквизнань та реплік-застережень:

- Виходь за мене, душко-пампушко, бо як не вийдеш, то я з горя скисну!

- Вийду, бо й ти мені полюбився, - нарешті призналася й пампушка [Мензатюк 2012 : 54]. Від усього того, в уяві малечі формується і первісна образна модель «смачної пари» страв.

Цікавим і своєрідним «узагальненням» видається остання казка 3 циклу смачних казочок 3. Мензатюк.

Так у творі «Калачі» авторка подає ретейкований фрагмент відомої народної української казки «Ходить гарбуз по городі». Але на цей раз калач, шукаючи своїх родичів, знаходить «білолицю» паляницю, вслід за якою обізвалися і макова баба, і пироги з рибою, із капустою, зі сливами та 3 родзинками, мандрики 3 сиром, кренделики та бублики, пундики, пряники, макорженики, медівники і сметанники та всілякі пиріжечки.

Усіма цими перерахунками родичів калача авторка не лише ще раз підкреслила багатство українських страв, а ще й здійснила деякі «територіальні» уточнення: $\epsilon$ «пиріжки київські 3 маслом», «пиріжки чернігівські з родзинками» тощо. А об’єднавшись, усі родичі борошняні створили смачне й велетенське «військо» для оборони від «Царя Голода». Так в уяві дитини всі ці вироби постають могутньою «зброєю» чи навіть «армією» порятунку від голодної смерті, яка має по-своєму долучити дітей до виробів із борошна.

Таким чином, цикл «смачних» та «апетитних» казочок З. Мензатюк, дуже вдало вводячи маленького читача у світ української кулінарії та кухні, не лише збагачує й формує вже наявні в уяві дітей густативні образи страв (від борщу до узвару з усім багатством борошняної дрібноти), а й робить їх значними та повноцінними, збагачує дитину знаннями про харчування українців, перетворюючи майже все це в казку, авторка 
упевнено вводить дитину в світ далеко не казкового кухонного «смачного буття українців».

Особливо видається цікавою казка про «хатинку з млинців», у якій подано не тільки й не стільки щедру реальність дитячого харчування, а й картини дитячих мрій та сновидінь.

Добре, що авторка не оминула й того, як інколи й самі батьки вдаються до вигадування незвичних ситуацій під час годування дітей.

\section{БІБЛІОГРАФІЯ}

Мензатюк 2012 - Мензатюк 3. Зварю тобі борщику / Зірка Мензатюк. Львів : Видавництво Старого Лева, 2012. - 58 с. 